\title{
LOGISTICS OF INTANGIBLE RESOURCES IN BUILDING A COMPETITIVE ADVANTAGE IN THEORETICAL TERMS
}

\begin{abstract}
The purpose of the article is to systematize the concepts related to the logistics of intangible resources. To accomplish this objective, the author has employed chiefly the methodology of a systematic review of literature. In the work, the author has raised issues concerning the theory of resources in building a competitive advantage also indicating how important it is to compile appropriate resources (tangible and intangible) to build such an advantage. Furthermore, taking into consideration the theory of a process approach to logistics, the author pinpoints the importance of intangible resources in logistics processes occurring in the course of building a competitive advantage.
\end{abstract}

Keywords: logistics of intangible assets, competitive advantage, information logistics, resources in logistics

JEL: L10, O10

\section{Introduction}

The current business environment is characterized by high volatility in terms of both business and technology. New ways of conducting business activities combining both the traditional theory of economy and IT industry solutions are becoming increasingly popular. Such an alliance results in the growing importance of e-business, and in taking up other activities aimed at reaching greater numbers of customers and having an effect on building a competitive advantage. Modern organizations rely not only on the flow of tangible resources, but it is the processing of intangible resources with special consideration given to the resource of information that are increasingly gaining in importance. Enterprises have started to see the potential in the access to information, its quality, acquisition and processing, 
and how important it is to absorb state-of-the-art IT solutions. IT solutions are increasingly important not only in organizations, the possibilities of adapting them in many areas of human life have defined a new stage in the development of humanity and the whole civilization. The fruit of such changes is the emergence of an information society, i.e. a relatively new form of society wherein the decisive role is played by the productive use of information and knowledge-oriented intensive production (Papińska-Kacperek, 2008). The dynamic development of information systems which are part of the information system combined with education and development of the information society has contributed to the development of economic systems and the growing complexity of relations between market players (Szmelter, 2013). Changes in organizations are driven by all these links enclosed within a loop, transferring the business to be conducted in an entirely different dimension which is most often virtual (Kalisz, Szyran-Resiak, 2018). The development of organizations of such type and the transfer of business into a virtual sphere result in an even greater change in the relation between intangible and tangible resources. Thus, a basic question is raised whether logistics-related theories require to be formulated or restructured anew due to the changing type of resources and the channel in which they flow. The change of both the resources and the channels in which they flow can be seen primarily in the implementation of digitization on a large scale, the automation of processes, the development of the Internet of Everything, the use of more and more advanced analyses of Big Data, while using cloud computing on a mass scale at the same time.

The purpose of the article is to systematize the theory related to the logistics of intangible resources and present the logistics role of intangible resources in building a competitive advantage, and proving that the essence of logistics is to control the processes of the flow of any resources (tangible and intangible) in any channels and between them, functioning between any users (physical and non-physical).

\section{Methodology and theory}

The main research problem of this study is the fact that there are no publications on the subject in the literature that would refer the theory of logistics to intangible resources which are gaining increasing importance in today's economy. The narrative (classic) literature review (bibliometric analysis, content analysis, narrative and descriptive review) was used to accomplish the assumed objective and ensure greater certainty in the process of verification of the formulated hypothesis. The system analysis method was employed to identify the resources which influence the building of a competitive advantage.

In many, even contemporary publications related to the theory of logistics, logistics is defined only and solely with reference to tangible resources (Qin, 2009; Abt, Woźniak, 1993; Gołembska, 1994) or to the flow of tangible resources and related information streams, with the understanding at the same time that information not related to physical movement is not subject to logistics operations (Christopher, 2011; Beier, Rutkowski, 1995; Skowronek, Sarjusz-Wolski, 1995; Garbarski et al., 1998; Fijałkowski, 2000). Some of the definitions of logistics found in the literature 
refer directly to tangible resources, information and other defined resources (Sudalaimuthu, Raj, 2009; Chaberek, 1999). However, few of such definitions refer to the enterprise's resources in the general meaning of the word (Krawczyk, 1998; Niziński, 1998; Chaberek, 2011, 2014). It is only the last group of authors that treat the approach to logistics in the terms of resources, without clearly defining the type of resources.

\section{Economic resources as a basis for competitiveness of economic activities}

Economic management, but also management in the broader sense, is human activity aimed at satisfying the arising human needs but also the needs expressed by other business entities. Cygan (1999) defines the essence of management as "allocation of disposable resources between various uses", which is the "human activity resulting from the pursuit of the fullest possible satisfaction of unlimited needs in the conditions of a limited nature of such resources". To complete the notion of the essence of management, it is worth noting that by reason of the continuous renewal and practically unlimited development of needs expressed by man, or more broadly, by the society, economic activity is continuous and uninterrupted in many areas, including, but not limited to production, distribution, exchange and consumption of goods (Milewski, Kwiatkowski, 2008).

In the traditional approach to economics, economic resources fall into the three main factors of production, namely, land capital and labour. Nonetheless, bearing in mind the development of management sciences and the popularization of the resource approach, it is necessary to extend these three factors by adding non-material factors in the form of the most important resource for decision-making processes, i.e. information (Weiland, 2017). Analyzing these factors, it should be assumed that labour is related to the use of human resources, financial resources and tangible resources are within the notion of capital, while land is related to the use of various natural resources. And information becomes an inseparable resource of every enterprise, although the above mentioned resources do not have to appear in the group of factors and resources of modern enterprises, every enterprise uses information resources. In the event of virtual enterprises and when running e-business in the broad sense of the word, information resources outweigh the tangible resources in terms of the quantity of flows. As a result of the growing importance of intangible assets in building a competitive advantage and the development of competences in management sciences, the classification of resources has been expanded to include an increasingly large collection of intangible resources. The importance of intangible resources grows proportionally to the process of transformation into a knowledge-based economy (Mikuła, 2018).

One of the major variants of classification of economic resources is their division into tangible and intangible assets (Bednarz, 2013). The category of tangible resources comprises: tangible fixed assets, plant and equipment, tangible current assets and financial assets. The group of intangible assets comprises human, 
market and organizational resources. Another example of classification has been proposed by Griffin (2010) who classifies resources of enterprises into four basic groups: human resources, financial resources, tangible resources and information resources. The fact that information resources have been included emphasizes their key importance for enterprises and for building a competitive advantage. It is the resources and skills and the way in which they are used by the organization that are strategic for its functioning as their weight translates into building a competitive and market advantage, as well as the ability to compete (Godziszewski, 2001). Nevertheless, it should be remembered that each resource has a different strategic value in building a competitive advantage, wherefore it is necessary to properly identify and evaluate them. A significant contribution to the development of the resource approach in organizations was made by Barney (1991) who defined the features of resources influencing the building of a competitive advantage. The "VRIN" approach proposed by him assumes that the useful resources in building the advantage should be:

- valuable;

- rare;

- inimitable;

- non-substitutable.

Summing up, the primary and original source of the competitive advantage are the enterprise's adequate tangible and intangible resources, but also the effective and efficient use of such resources. If resources should contribute to building a competitive advantage, their configuration has to be unique (Czerniachowicz, 2016), and they should fulfill the following goals: the adequate resource should be in the right place, at the right time and in the right amount, and its cost should be acceptable.

\section{Logistics of intangible resources in the process of creating value and building a competitive advantage}

As has been previously noted in the literature, it is possible to distinguish many different definitions of logistics. The difficulty to define logistics clearly results mostly from its nature and the source of origin, i.e. socio-economic sciences. Nevertheless, following a detailed analysis of the definitions in terms of the subject matter of this work, it is possible to distinguish many common features among them, whereby they can be grouped by the object of logistics activities. A categorization of the definitions by the object of logistics is presented in Table 1 . 
Table 1. Definitions of logistics categorized by subject

\begin{tabular}{|c|c|c|c|c|}
\hline $\begin{array}{c}\text { Object } \\
\text { of logistics }\end{array}$ & $\begin{array}{l}\text { Tangible resources, } \\
\text { including those } \\
\text { defined as products }\end{array}$ & $\begin{array}{l}\text { Tangible resources } \\
\text { and related } \\
\text { information flows }\end{array}$ & $\begin{array}{c}\text { Tangible, } \\
\text { information } \\
\text { and other defined } \\
\text { resources }\end{array}$ & $\begin{array}{c}\text { Generally } \\
\text { presented resources } \\
\text { without clear } \\
\text { definition }\end{array}$ \\
\hline $\begin{array}{l}\text { Author, } \\
\text { publication } \\
\text { date }\end{array}$ & $\begin{array}{l}\text { American } \\
\text { Marketing } \\
\text { Association, 1935, } \\
1948 \text { (Qin, 2009) } \\
\text { National Council } \\
\text { of Physical } \\
\text { Distribution } \\
\text { Management, } 1960 \\
\text { (Qin, 2009) } \\
\text { (Lalonde et al., } \\
\text { 1970) } \\
\text { Japanese } \\
\text { Comprehensive } \\
\text { Research Institute } \\
\text { 1981 (Qin, 2009) } \\
\text { (Abt, Woźniak, } \\
\text { 1993) } \\
\text { European Logistics } \\
\text { Association, 1994 } \\
\text { (Qin, 2009) } \\
\text { (Gołembska, 1994) } \\
\text { (Skowronek, } \\
\text { Sarjusz-Wolski, } \\
\text { 1995) } \\
\text { Cox M.D., } \\
\text { LogLink/ Logistics } \\
\text { World, 1997 } \\
\text { (Sudalaimuthu, Raj, } \\
\text { 2009) }\end{array}$ & $\begin{array}{l}\text { Council of Logistics } \\
\text { Management, 1985 } \\
\text { (Qin, 2009) } \\
\text { (Christopher, 1992) } \\
\text { (Beier, Rutkowski, } \\
\text { 1993) } \\
\text { (Blaik, 1997) } \\
\text { Canadian } \\
\text { Association } \\
\text { of Logistics } \\
\text { Management, 1998 } \\
\text { (Sudalaimuthu, Raj, } \\
\text { 2009) } \\
\text { Council of Logistics } \\
\text { Management, 1998 } \\
\text { (Sudalaimuthu, Raj, } \\
\text { 2009) } \\
\text { (Garbarski et al., } \\
\text { 1998) } \\
\text { (Fijałkowski, 2000) }\end{array}$ & $\begin{array}{l}\text { (Sudalaimuthu, Raj, } \\
\text { 2009) } \\
\text { (Chaberek, 1999) }\end{array}$ & $\begin{array}{l}\text { (Krawczyk, 1998) } \\
\text { (Niziński, 1998) } \\
\text { (Chaberek, 2011, } \\
\text { 2014) }\end{array}$ \\
\hline
\end{tabular}

Source: (own elaboration based on: Qin, 2009; Lalonde et al., 1970; Christopher, 2011; Abt, Woźniak, 1993; Beier, Rutkowski, 1995; Gołembska, 1994; Skowronek, Sarjusz-Wolski, 1995; Blaik, 1997; Grabarski et al., 1998; Krawczyk, 1998; Niziński, 1998; Fijałkowski, 2000; Chaberek, 1999, 2011, 2014)

From the perspective of the subject matter of this article, the author draws attention to definitions which do not clearly indicate the resources being the object of logistics. Krawczyk (1998) indicates that logistics comprises planning, coordination and control of the progress of processes carried out to achieve the assumed goals both in time and space. Hence, the definition does not clearly give any indication as to what processes are covered by logistics and what resources should be provided to implement these processes. At the same time Niziński (1998) defines logistics as a field of knowledge about rational, comprehensive and economical mass-energy and information security for the functioning of operating systems using the existing resources, limitations and disruptions in the set conditions and time. This definition 
also shows the freedom of use in terms of resources, limitations and disruptions at the specific time and under the specific conditions of the operation of an enterprise. From the author's perspective it is the definitions proposed by Chaberek $(1999,2011,2014)$ that are of key importance. The first of these (1999) defines logistics as the control of the flow of all resources within businesses and non-commercial organizations and between these organizations in logistics channels and chains. This definition emphasises the role of all resources required from the point of view of a given process. The second definition of logistics proposed in 2011 (Chaberek, 2011) describes it as a process aiming to support any rational human activity focused on realizing any objective to provide adequate resources at the right place and time, in an adequate quantity and at a reasonable cost (price) in such a way that all the activities to realize the main objective are carried out in an efficient, effective and beneficial manner. In 2014, this definition was slightly modified in terms of logistics goals (Chaberek, 2014) compared to the previously mentioned definition of six logistics goals (6R), it was replaced with five goals (5R). In the author's opinion, from the perspective of the subject matter of this work, this is the best definition of logistics by reason of its universal nature. This definition indicates directly that the subject matter of logistics are all the resources required to carry out any process that plays the role of the main process. Logistics plays a support function with respect to the main process, providing all the required resources in accordance with the logistics goals $(5 \mathrm{R})$, so that the whole process of realizing the main objective (main process) should be implemented in an efficient, effective and beneficial way. Hence, it should be assumed that any process defined by the enterprise as main that is aiming to accomplish the pursued goal requires implementing supporting processes which are logistics processes. Therefore, the role of logistics processes is optimal (in line with the five goals of logistics) management of the available resources. From the perspective of the author of the publication and its subject matter, it should be assumed that the major process is the process of building a competitive advantage with the aim to develop this advantage in a specific time and under specific conditions. The supporting logistics processes have to provide adequate resources from the perspective of the main process implementation, these being both tangible and intangible resources, since, as indicated in a previous section of this article, the adequate compilation of these two types of resources has an effect on building a competitive advantage. The relationship between the process of building a competitive advantage and the logistics process is presented in Figure 1.

While the logistics of tangible resources is widely accepted by many in the world of both science and practice, the logistics of intangible resources arouses many emotions and controversies. Nevertheless, irrespective of whether science will argue about the existence of information logistics or, reaching farther, the logistics of intangible resources, the economic practice shows that the operation of intangible resources allows building a competitive advantage and it is extremely important from the point of view of the organization. The controversies are caused chiefly due to the lack of a clear definition of intangible resources and no clear indication which resources are intangible. The simplest way would be to assume that intangible resources are everything that does not have a material form but has nonetheless impact on building the enterprise's value and is necessary for accomplishing 
the pursued goal. Nevertheless, it should be noted that each and every intangible resource is linked to the corresponding carrier of this asset. With this approach to intangible resources, it should be assumed that an intangible resource creates some kind of added value to a tangible resource, which means that we can talk about the existence of carriers of intangible resources, where an example can be information and its carrier, i.e. data stored on hard disks, portable memory servers, in the case of knowledge the carriers are people with adequate knowledge and skills, in the case of software and other forms of IT tools, the carriers are similar as in the case of information. However, as far as organizational intangible assets are concerned, their carriers may be a combination of many tangible resources, which, by achieving a synergistic effect, create an added value that is intangible.
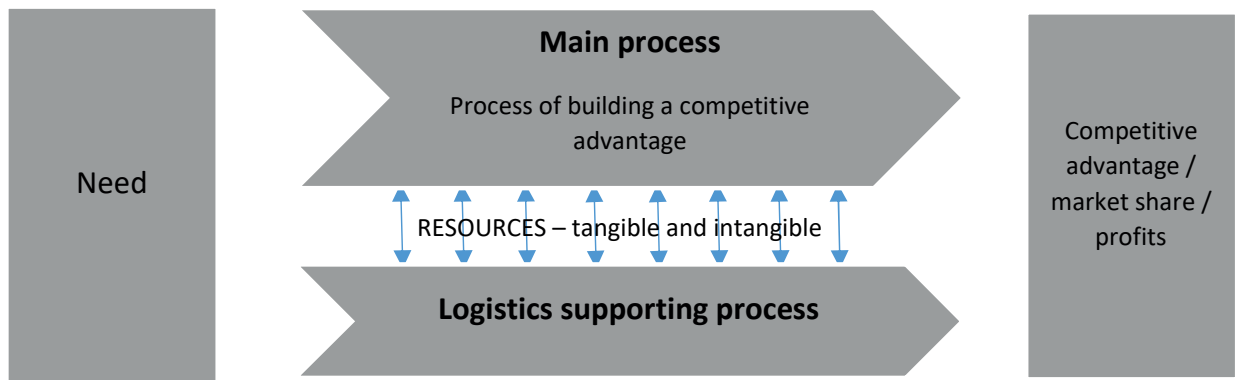

Figure 1. The process of building a competitive advantage and the supporting logistics process

Source: (own elaboration based on: Chaberek, 2002)

The importance of intangible resources in logistics processes, as well as their role as the subject of these processes, will be continuously increasing as a result of technical development. A few years ago only, any reference to teleportation of anything would appear solely in sci-fi movies and related literature. However, the development of technology has contributed to the fact that this concept, fantastic until recently, has become a fact. It is possible already today to teleport the quantum state (Sobota, 2014), which may contribute to the teleportation of information and data. Therefore, it becomes very likely that tangible (material) resources will have a part of their flow in an immaterial form in the future. Obviously, talking about teleportation requires a two-dimensional logistics approach - due to the virtual resource and due to the development of new virtual logistics channels.

Summing up, the building of a competitive advantage and the process of creating the value of enterprises is influenced by both tangible and intangible resources. Hence, assuming that the process of building a competitive advantage is the main process, the essence of logistics (reflected in logistics supporting processes) is to control the supporting processes in such a way that they should ensure resources, whether tangible or intangible, in any logistics channels (virtual, traditional) and between these channels which function between any users, both physical (people) and organizations or non-physical resources (machines, software, virtual units). The importance of intangible resources seems to be growing year by year. While tangible resources such as natural resources, as well as the products 
manufactured from them will probably be irreplaceable in the long term continuing to be very important in the process of economic development (Krawiec, 2009), the technological progress as well as digitization and virtualization understood in the broad sense will become the driving force for earning high profits and increasing the efficiency and effectiveness of activities in the intangible sphere. This state of affairs finds confirmation in the market value, amounting to billions of dollars, of entities focusing their activities exclusively on the virtual sphere, e.g. Google, Facebook, Microsoft and many others (Mazurek, 2012).

\section{Conclusions}

Tangible and intangible resources, and in fact, their compilation and fulfilment of logistics goals in this respect, namely, ensuring the appropriate resources, in the right place, at the right time and in the right quantity and at an acceptable cost are the basis for building a competitive advantage. Taking this approach, it should be assumed that the object of logistics are both tangible and intangible resources. Hence, we can talk about logistics of intangible resources by reason of the object of logistics. The scientific development combined with the simultaneous development of the IT sector gives unimaginable possibilities for creating new intangible resources, but also creates new channels for the their movement. Owing to the virtualization of enterprises creating completely new forms and ways of conducting business it can be said that the users of resources in these channels are both physical and virtual users. Taking into account the growing importance of intangible resources in the contemporary economy as well as the development of new channels of movement of these resources, subsequent research of logistics of intangible resources is needed.

\section{References}

Abt, S., Woźniak, H. (1993), Podstawy logistyki, Wydawnictwo Uniwersytetu Gdańskiego, Gdańsk, p. 19.

Barney, J. (1991), Firm Resources and Sustained Competitive Advantage. Journal of Management, 17(1), pp. 99-120.

Bednarz, J. (2013), Konkurencyjność polskich przedsiębiorstw na rynkach europejskich, Wydawnictwo Uniwersytetu Gdańskiego, Gdańsk, p. 178.

Beier, F. J., Rutkowski, K. (1995), Logistyka, Szkoła Główna Handlowa, Warszawa, p. 16.

Blaik, P. (1997), Logistyka. Koncepcja zintegrowanego zarządzania przedsiębiorstwem, Polskie Wydawnictwo Ekonomiczne, Warszawa, pp. 14-15.

Chaberek, M. (1999), Logistyka - dawne i współczesne płaszczyzny praktycznego jej stosowania. Pieniądze $i$ Więź, 4(3), p. 139.

Chaberek, M. (2002), Makro- i mikroekonomiczne aspekty wsparcia logistycznego, Wydawnictwo Uniwersytetu Gdańskiego, Gdańsk, p. 14.

Chaberek, M. (2011), Praktyczny wymiar teorii logistyki. Roczniki Naukowe Wyższej Szkoty Bankowej w Toruniu, 10(10), p. 211.

Chaberek, M. (2014), Theoretical, Regulatory and Practical Implications of Logistics. Logforum, $10(1)$, p. 6.

Christopher, M. (2011), Logistics \& Supply Chain Management, FT Press, London, p. 2. 
Cygan, A. (1999), Racjonalność gospodarowania. In: Dach, Z. (Ed.), Wprowadzenie do ekonomii, Wydawnictwo Akademii Ekonomicznej, Kraków, p. 50.

Czerniachowicz, B. (2016), Zasoby niematerialne i kapitał intelektualny a wartość przedsiębiorstwa. Finanse, Rynki Finansowe, Ubezpieczenia, 4(82), part 2, pp. 373-382, doi: 10.18276/ frfu.2016.4.82/2-32.

Fijałkowski, J. (2000), Transport wewnętrzny w systemach logistycznych - wybrane zagadnienia, Oficyna Wydawnicza Politechniki Warszawskiej, Warszawa, p. 165.

Garbarski, L., Rutkowski, I., Wrzosek, W. (1998), Marketing. Punkt zwrotny nowoczesnej firmy, Polskie Wydawnictwo Ekonomiczne, Warszawa, p. 390.

Godziszewski, B. (2001), Zasobowe uwarunkowania strategii przedsiębiorstwa, Wydawnictwo Uniwersytetu Mikołaja Kopernika, Torun, p. 76.

Gołembska, E. (1994), Logistyka jako zarządzanie całym łańcuchem dostaw, Wydawnictwo Akademii Ekonomicznej, Poznań, p. 90.

Griffin, R. W. (2010), Podstawy zarządzania organizacjami, Wydawnictwo Naukowe PWN, Warszawa, p. 5.

Kalisz, D., Szyran-Resiak, A. (2018), Organizacja wirtualna w erze społeczeństwa informacyjnego. Zeszyty Naukowe Państwowej Wyższej Szkoły Zawodowej w Płocku. Nauki Ekonomiczne, 28, pp. 483-495, doi: 10.19251/ne/2018.28(31).

Krawczyk, S. (1998), Logistyka w zarządzaniu marketingiem, Wydawnictwo Akademii Ekonomicznej im. Oskara Langego, Wrocław, p. 33.

Krawiec, F. (2009), Nowa gospodarka i wizja lidera firmy XXI wieku, Difin, Warszawa, p. 34.

Lalonde, B. J., Grabner, J. R., Robeson, J. F. (1970), Integrated Distribution Management: A Management Perspective. International Journal of Physical Distribution, 1(1), p. 43.

Mazurek, G. (2012), Znaczenie wirtualizacji marketingu w sieciowym kreowaniu wartości, Wydawnictwo Poltext, Warszawa, p. 32.

Mikuła, B. (2018), Zarządzanie oparte na wiedzy - podstawowe założenia. Studia Ekonomiczne, Gospodarka, Społeczeństwo, Srodowisko, 1(2), pp. 3-46.

Milewski, R., Kwiatkowski, E. (2008), Podstawy ekonomii, Wydawnictwo Naukowe PWN, Warszawa, p. 7.

Niziński, S. (1998), Logistyka w systemach działania, Polskie Towarzystwo Diagnostyki Technicznej - Wydawnictwo i Zakład Poligrafii Instytutu Technologii Eksploatacji, Warszawa-Radom, p. 29.

Papińska-Kacperek, J. (2008), Społeczeństwo informacyjne, Wydawnictwo Naukowe PWN, Warszawa.

Qin, Z. (Ed.) (2009), Introduction to E-commerce, Tsinghua University Press, Beijing, pp. 248-249.

Skowronek, C., Sarjusz-Wolski, Z. (1995), Logistyka w przedsiębiorstwie, Polskie Wydawnictwo Ekonomiczne, Warszawa, p. 16.

Sobota, M. (2014), Teleportacja nieznanego stanu kwantowego. Zeszyty Naukowe Politechniki Śląskiej. Organizacja i Zarządzanie, 68, pp. 397-402.

Sudalaimuthu, S., Raj, S. A. (2009), Logistics Management for International Business: Text and Cases, PHI Learning Pvt. Ltd., New Delhi, p. 2.

Szmelter, A. (2013), Business Intelligence Tools as an Element of Information Supply System. Toruń Business Review, 12(12), pp. 127-142. Available from https://tbr.wsb.torun.pl/index. php/journal/article/view/236 [Accessed 17 February 2019].

Weiland, D. (2017), The Role of Information in e-Commerce. Transport Economics and Logistics, 68, pp. 103-115, doi: 10.5604/01.3001.0010.5326.

\section{Corresponding author}

Dariusz Weiland can be contacted at: d.weiland@ug.edu.pl 